\title{
A novel single-stage PWM microinverter topology using two-power switches
}

\author{
A. Razi ${ }^{1}$, M. Nabil Hidayat ${ }^{2}$, M. N. Seroji ${ }^{3}$, S. Z. Mohammad Noor ${ }^{4}$ \\ ${ }^{1}$ Center for Robotics and Industrial Automation (CeRIA), Universiti Teknikal Malaysia, Malaysia \\ 1,2,3,4 Centre of Electrical Power Engineering Studies (CEPES), Universiti Teknologi MARA, Malaysia
}

\begin{tabular}{l}
\hline Article Info \\
\hline Article history: \\
Received Oct 20, 2019 \\
Revised Dec 28, 2019 \\
Accepted Jan 17, 2020 \\
\hline
\end{tabular}

Keywords:

Harmonic

Microinverter

Photovoltaic

Single-stage

SPWM

\begin{abstract}
This paper presents a novel single-stage microinverter topology using only two-power switches. The number of components count are directly proportional to the power losses, weight, cost and complexity of the design. Nowadays, conventional Microinverter without transformer having minimum of six power switches, while only three power switches involved in a Microinverter structure with the presence of a transformer. Thus, this paper proposed a novel Microinverter topology with only two-power switches to convert DC-voltage from Photovoltaic (PV) module to an AC-output. Modes of operation and current flow during each cycle are being explained. Variation of modulation index, irradiance and temperature of the PV module, the switching frequency and harmonic content of the proposed Microinverter are being analysed. A simulated model of Microinverter topology, employed only two power switches with a standard Unipolar Sinusoidal Pulse Width Modulation (SPWM) having $0.85 \%$ harmonic percentage; able to inject current to the load; have been successfully built and demonstrated through simulation based on MATLAB/Simulink, thus provide theoretical validation for further research.
\end{abstract}

This is an open access article under the CC BY-SA license.

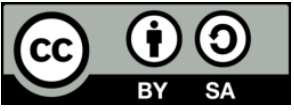

\section{Corresponding Author:}

\section{A. Razi,}

Center for Robotics and Industrial Automation (CeRIA),

Fakulti Kejuruteraan Elektrik,

Universiti Teknikal Malaysia Melaka, Jalan Hang Tuah Jaya, 76100 Durian Tunggal, Melaka.

Email: atikah@utem.edu.my

\section{INTRODUCTION}

Microinverter is popular among industrial and research field due to its great advantages in terms of compact design, lesser number of components involved, and efficiency-factor compared to other structure of Photovoltaic (PV) system [1-9]. Therefore, the background study on PV application (Centralized, String, and Microinverter) reveals that the Microinverter becomes the trend for the next generation of system development $[1,4,5,10]$.

There are two classification of power conversion process in Microinverter; Two-stage or Singlestage. Classical Microinverter adopted two-stage of power conversion which has been broadly used in the PV system [1, 11-13]. Two-stage Microinverter usually deal with power interface challenge between unstable DC-voltage source to stable high DC-voltage value before transforming into AC-voltage output [2, 5, 14]. Furthermore, two-stage Microinverter contains large number of components count [2, 15, 16], in order to realize converter and inverter power conversion stage which includes semiconductor devices, inductor, capacitor, and/or diode. Higher components count leads to higher switching losses and production/maintenance cost [16-18]. In addition, some of the converter and inductor topology may comprise 
transformer [2, 6, 7, 19-22] to step-up the voltage value. Consequently, the Microinverter structure become bulky. The best is to have minimum stage of power conversion, hence Single-stage Microinverter topology, for ease in module integration. Thus, its strong to say that inverter topology is a major area of interest to employed less number of components. These number of components inside the topology are significantly affected the switching losses, the overall size, control stratergy of the power switches, and manufacturing cost of the Microinverter.

Single-stage Microinver can be categorized based on galvanic isolation [23]; Transformer-based inverter or Transformer-less inverter. Early years of Single-stage Microinverter history, the topology were build with the present of transformer. Microinverter with classical-Flyback topology [7] with 3-power switches in 1998 in conjuction with the line-frequency transformer for circuit isolation purposes. Later in 2015, an auxiliary circuit were added to the Flyback-topology that allows the switch and diode at the primary side of the transformer could be turn on using soft-switching operation. In 2014, Attanasio et. al [2] allows for AC-waveform to be generated by the using of 4-power switches and the existing of a line-transformer after the filter components for protection plan. However, Aganza-Torres et. al in 2014 [19] implemented 10power switches to overcome the bigger value of decoupling capacitor. Later in 2016 [2], 6-power switches with series of resonant tank were proposed for Zero Voltage Switching (ZVS) thus minimized the switching loss. A Half-bridge Microinverter topology utilizing 4-power switches were proposed by V. Berzan et. al in 2016 [20] employed an alternating current source (SAC) to generated AC-waveform with soft switching technique.

Transformer-based topology is one of major concerned in Single-stage Microinverter due to the larger space contributed by the transformer, hence a transformer-less structure arrangement was introduced to overcome the concern. Y. Fang and X. Ma in 2010 [24] proposed a coupled-inductor to a 4-power swicthes double-boost topology to solve the voltage gain issue in Microinverter. However, a complex DSP controller were implemented when a simpler digital controller can be used for Microinverter under 300W application [25]. Another technique for single-stage Microinverter was using Hysteresis Controller; having current and voltage controller proposed by D. Petreus et. al in 2013 [1]. The Hysteresis Controller were implemented into 5-power switches of dual buck-boost Microinverter topology. In 2018, a Boost PWM Inverter [26] with total of 4-switches with a flying capacitor to eliminate the leakage current. However, a minimum of 7-level microinverter topology were build in order to reach 400V DC voltage before undergone the inverter process.

Considering the above aspects, this paper presents a novel Single-stage transformer-less Microinverter topology using only 2-power switches which is straightforwardly implemented with single PV module usually targeted for the residential application with less than $1 \mathrm{~kW}$. The proposed Microinverter topology only use single active power devices during each cycle. The trend of the expected power delivered by the PV-module, the trend of output current and harmonic content with respect to modulation index and switching frequency were analyzed. Overall, the proposed Single-stage Microinverter topology using 2power switches producing as low as $0.85 \%$ harmonic content which successfully built and demonstrated through simulation based on MATLAB/Simulink, thus provide theoretical validation for further research.

\section{PROPOSED MICROINVERTER TOPOLOGY}

The proposed topology is constructed based on the idea of positive AC-cycle is activated by single power switch while the other negative AC-cycle is activated by another single power switch. The uniqueness of this topology underlies in the fact that a sine wave is generated by only using 2-power switches and using single PV module. This can be achieved by supplying only one power source which then charging and discharging the two-parallel capacitors and filtering-inductor connected across point- $\mathrm{A}$ and point-B of the circuit topology, as illustrated in Figure 1. The power switches; S1 and S2, having 50\% of the duty cycle.

\subsection{Photovoltaic (PV) module}

Photovoltaic module (PV) is a dominant feature for Microinverter topology design. PV module absorb irradiance from solar energy and turns into electricity. Normally, one PV module has 60-cell per module or up to 120-cells in the same area. Number of cells inside single PV module will determine the module efficiency. Determine the PV module could be the very first step in designing the PV system application. Trina Solar Framed 72-cell 330W Module [27] was chosen for this paper and its datasheet is shown in Table 1; during STC (Irradiance $1000 \mathrm{M} / \mathrm{w}^{2}, T_{\text {cell }} 25^{\circ} \mathrm{C}$ ) and during NOCT (Irradiance $800 \mathrm{M} / \mathrm{w}^{2}$, $T_{\text {ambient }} 20^{\circ} \mathrm{C}$ ). The expected electrical power; $P_{R O C}$ generated from the PV module when placed outside (on top of the roof), with specific irradiance, $G$ can be determined by (1) - (6) [28]; where $k_{\text {dirt }}$ and $k_{\text {age }}$ are $2 \%$ and 1 respectively for a new PV module. While the derating factors are; $k_{\text {power_deration }}$ is total de-rating factors related to power, $k_{m m_{-} p}$ is de-rating factor due to module mismatch power, $k_{t e m \_} p$ is de-rating factor 
of power due to cell temperature, $k_{\text {dirt }}$ is de-rating factor due to dirt, and $k_{a g e}$ is de-rating factor of power due to ageing. All these de-rating factor must me in decimal point.

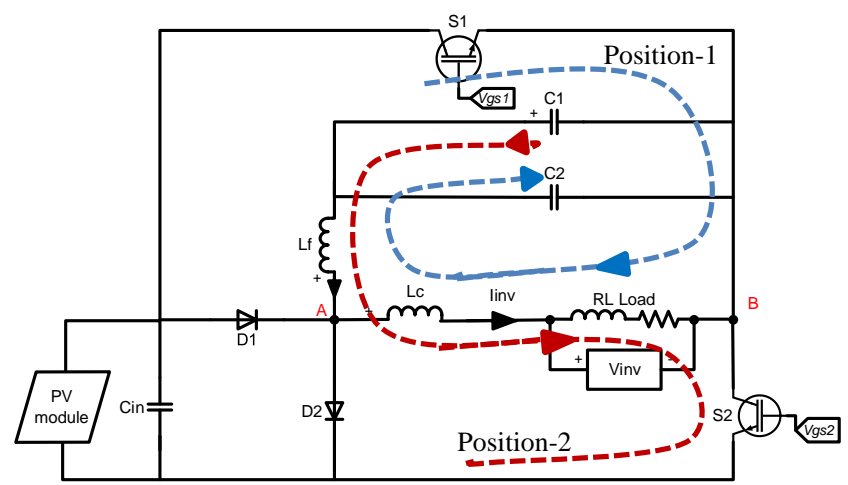

Figure 1: Proposed topology with two parallel-capacitor.

Table 1: Photovoltaic Module datasheet during STC and NOCT [27]

\begin{tabular}{ll}
\hline \multicolumn{3}{c}{ Model Trina Solar Framed 72-cell $330 \mathrm{~W}$ module } \\
During STC (Irradiance $1000 M / w^{2}, T_{\text {cell }} 25^{\circ} \mathrm{C}$ ) \\
\hline Peak Power, $P_{M P}(\mathrm{~W})$ during STC $\left(P_{S T C}\right)$ & $330 \mathrm{~W}$ \\
Maximum Power Voltage, $V_{M P}(\mathrm{~V})$ & $37.4 \mathrm{~V}$ \\
Maximum Power Current, $I_{M P}(\mathrm{~A})$ & $8.83 \mathrm{~A}$ \\
Open Circuit Voltage, $V_{O C}(\mathrm{~V})$ & $45.8 \mathrm{~V}$ \\
Short Circuit Current, $I_{S C}(\mathrm{~A})$ & $9.28 \mathrm{~A}$ \\
Module Efficiency, $\eta(\%)$ & $17 \%$ \\
\hline \multicolumn{2}{l}{ During NOCT (Irradiance $\left.800 M / w^{2}, T_{a m b i e n t} 20^{\circ} \mathrm{C}\right)$} \\
\hline Maximum Power, $P_{M P}(\mathrm{~W})$ during NOCT & $245 \mathrm{~W}$ \\
Maximum Power Voltage, $V_{M P}(\mathrm{~V})$ & $34.6 \mathrm{~V}$ \\
Maximum Power Current, $I_{M P}(\mathrm{~A})$ & $7.08 \mathrm{~A}$ \\
Open Circuit Voltage, $V_{O C}(\mathrm{~V})$ & $42.4 \mathrm{~V}$ \\
Short Circuit Current, $I_{S C}(\mathrm{~A})$ & $7.49 \mathrm{~A}$ \\
\hline
\end{tabular}

$$
\begin{array}{r}
P_{R O C}=P_{S T C} x k_{\text {power_deration }} \\
k_{\text {power_deration }}=k_{m m_{\_} p} x k_{\text {tem } \_p} x k_{g} x k_{\text {dirt }} x k_{\text {age }} \\
k_{m m_{-} p}=1-\text { power tolerance }
\end{array}
$$

\subsection{Principle of operation}

When the switch at position-1 (referring to Figure 1) is in high state, the parallel-capacitor in gets connected to the input supply and charge-mood ON thus positive voltage is observed at the output. Subsequently, as the switch in position-2 turns high, the parallel-capacitor tends to discharge and hence a negative voltage is observed at the output. The above positions are being repeated at high switching frequency to maintain a constant voltage across the load. Principle of illustrating the charging and discharging the parallel-capacitor are being marks by blue-dotted and red-dotted line respectively. Conclusively, switch S1 charges the parallel-capacitor while switch S2 discharges it thereby. From the power perspective, the output current, voltage, and power equation of the output waveforms can be referred in the (10) [29]. Where; $I_{\text {inverter }}$ is the inverter output current, $V_{\text {inverter }}$ is the inverter output load voltage, while $P_{\text {inverter }}$ is the inverter output power. Inverter output power in (9) can be transformed into (10) by using Mathematical transformation. In (10), $2 \omega$ can be substituted with $\omega=2 \pi f$; where $f$ is the grid frequency of $50 \mathrm{~Hz}$.

\subsection{Control and modulation strategy}

The proposed Microinverter modulation is handled using a standard unipolar Sinusoidal Pulse Width Modulation (SPWM), as shown in Figure 2. The unipolar SPWM normally requires two sinusoidal waves which are of same magnitude and frequency but $180^{\circ}$ out of phase as depicted in Figure $2 \mathrm{a}$. The two modulating waves are compared with a common triangular carrier wave generating two gating signals for switch S1 and S2 respectively. Here, switch S1 is modulated in reference to the positive sinusoidal to generate the positive grid cycle and switch S2 is modulated with negative sinusoidal reference (with $\pi$ phase) 
to create the negative half of the grid cycle. Hence, only one switch carries the inverter's current, $I_{\text {inv }}$ during the positive as well as the negative cycle. The charging of the parallel-capacitor is achieved through switch S1 during positive cycle. These two switches experience high frequency switching during both the positive and negative cycle, thereby ensuring voltage control over the capacitors. The switching sequence for a singlephase construction is shown in Table 2.

Table 2: Switching states of the proposed Microinverter

\begin{tabular}{lccc}
\hline State & S1 & S2 & Vload \\
\hline Zero state & 0 & 0 & 0 \\
Positive state & 1 & 0 & Vin/2 \\
Negative state & 0 & 1 & - Vin/2 \\
Zero state & 1 & 1 & $\sim 0$ \\
\hline
\end{tabular}

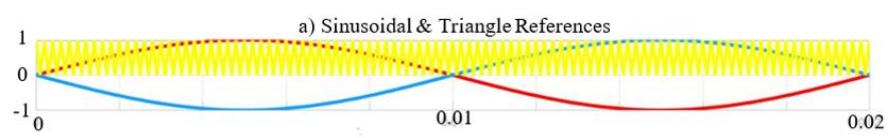

(a)

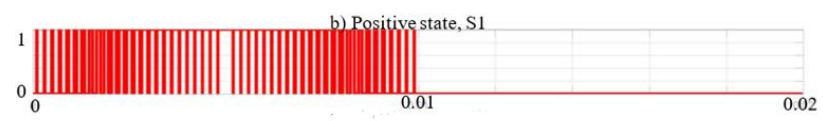

(b)

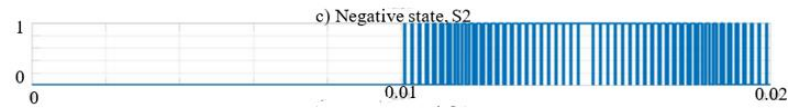

(c)

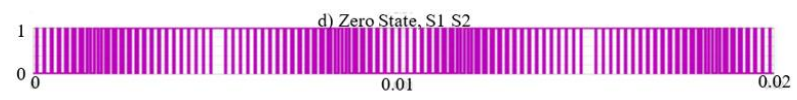

(d)

Figure 2: Unipolar SPWM for the proposed microinverter topology: (a) Sinusoidal \& triangle references, (b) Positive satte S1, (c) Negative S2, (d) Zero state S1 S2

\subsection{Modes of operation}

To satisfy the power conversion process, two modes of operation have been derived for this topology. The switching sequence for a single-phase construction is shown in Table 2 and Figure 3 show the equivalent circuit of the proposed microinverter topology during switching states.

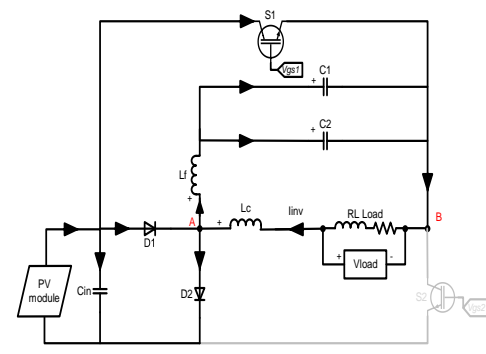

(a)

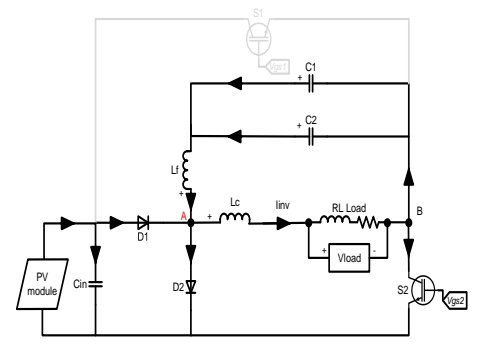

(b)

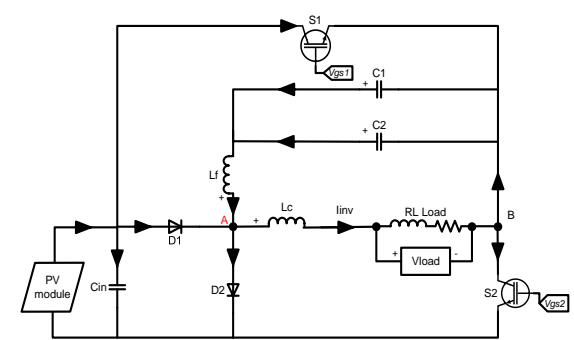

(c)

Figure 3: Equivalent circuit of the proposed microinverter topology during switching states: (a) Positive state, (b) Negative state, and (c) Zero state 


\subsubsection{Positive state}

The positive modulating signal is subjected for comparison to a reference triangular waveform in order to generate the required pulse for switch $\mathrm{S} 1$. Thus, creating a gate pulse for switch $\mathrm{S} 1$ during this state while switch S2 remain OFF for the complete positive cycle. This ensures the parallel-capacitor charging in this stage. High frequency switching helps to reduce the size of the capacitors. The gate pulse for switch S1 and the flow of current during this state are represented in Figure $2 b$ and Figure $3 a$ respectively.

\subsubsection{Negative state}

The negative modulating signal with a phase angle of $180^{\circ}$ is subjected for comparison to a reference triangular waveform in order to generate the required pulse for switch $\mathrm{S} 2$. Thus, creating a gate pulse for switch S2 during this state while switch S1 remain OFF for the complete negative cycle. The gate pulse for switch S2 and the flow of current during this state are represented in Figure 2c and Figure $3 \mathrm{~b}$ respectively.

\subsubsection{Zero state}

There are two zero-state conditions for this topology. First zero-state condition is created by turning OFF both switches. At this moment, there is no output coming out from the microinverter. Both output current, $I_{i n v}$ and load voltage, $V_{\text {load }}$ are equal to zero. Second zero-state condition happens when both switches are active at the same time. At this moment, both output current, $I_{\text {inv }}$ and load voltage, $V_{\text {load }}$ are cancelling each other from positive and negative state, therefore produced nearly zero output, as shown in Figure $3 \mathrm{c}$. Bare in minds that, zero-state conditions for this topology only occur at very short time during the transitions between negative and positive state. The gate pulse and the flow of current during zero state are represented in Figure 2d and Figure $3 \mathrm{c}$ respectively.

\section{SIMULATION RESULTS}

Numerical simulation of the proposed Microinverter is conducted to verify the performance of the topology. Simulation was performed by using MATLAB/Simulink, in a detailed model. To demonstrate the circuit principle, the PV module from Trina Solar Framed 72-cell Module is used. The parameters and components realised for MATLAB/Simulink simulation are listed in Table 3.

\subsection{Trend of $I_{\text {inverter }}$ and THD with respect to Fs}

The switching frequency, $f_{s}$ were varied from $5 \mathrm{kHz}, 10 \mathrm{kHz}, 25 \mathrm{kHz}$ and $50 \mathrm{kHz}$, in order to analyse the impacts on the output current, $I_{\text {inverter }}$ and harmonic content, THD of the proposed Single-stage Microinverter. The irradiance and temperature of the PV module were fixed according to STC condition (Irradiance $1000 \mathrm{M} / \mathrm{w}^{2}, T_{\text {cell }} 25^{\circ} \mathrm{C}$ ). The modulation index was fixed, $\mathrm{Ma}=1$.

Figure 4 illustrates the trend between output current, $I_{\text {inverter }}$ and THD with respect to switching frequency, $f_{s}$. The switching frequency, $f_{s}$ affected the amplitude of the output current, $I_{\text {inverter }}$ as the switching frequency, $f_{s}$ become higher, the amplitude of output current, $I_{\text {inverter }}$ decreased since the charging and discharging times of the parallel-capacitor become significantly shorter with an increase in switching frequency, $f_{s}$ (change from $10 \mathrm{kHz}, 25 \mathrm{kHz}$ and $50 \mathrm{kHz}$ ). The harmonic content, THD also decreases when the switching frequency, $f_{s}$ increases, since it requires less time to complete one cycle.

Table 3: Proposed microinverter parameters

\begin{tabular}{ccc}
\hline Parameter & Variable & Value \\
\hline PV module & $P_{m p}$ & $330 \mathrm{~W}$ \\
DC link capacitor & $C_{i n}$ & $400 \mu \mathrm{F}$ \\
Grid frequency & $f$ & $50 \mathrm{~Hz}$ \\
Switching freqeuncy & $f_{s}$ & $50 \mathrm{kHz}$ \\
Parallel-capacitor 1 & $C_{1}$ & $20 \mu \mathrm{F}$ \\
Parallel-capacitor 2 & $C_{2}$ & $20 \mu \mathrm{F}$ \\
Inductor filter & $L_{f}$ & $150 \mathrm{mH}$ \\
Coupling inductor & $L_{c}$ & $150 \mathrm{mH}$ \\
Load & $R, L$ & $10 \Omega, 5 \mathrm{mH}$ \\
Power switches & $S 1, S 2$ & IGBTs \\
Diodes & $D 1, D 2$ & - \\
\hline
\end{tabular}




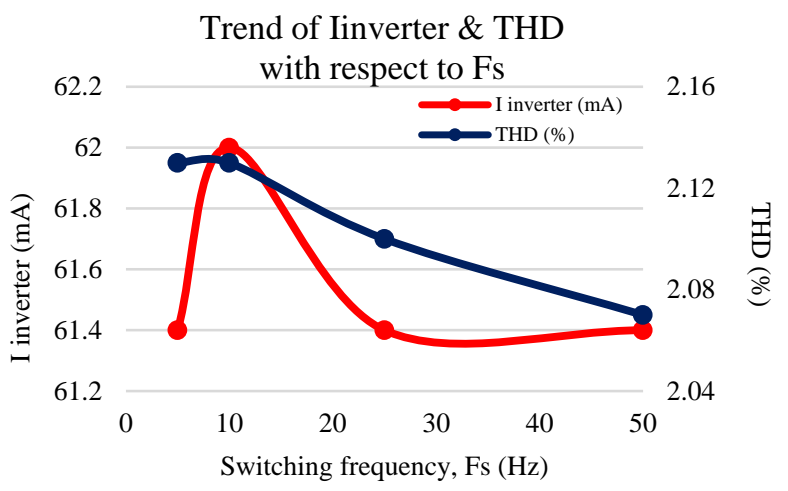

Figure 4: Trend of output current, $I_{\text {inverter }}$ and THD percentage with respect to switching frequency, $f_{s}$

\subsection{Trend of $I_{\text {inverter }}$ and THD with respect to Ma}

The modulation index, Ma for both SPWM $\left(\varnothing=0\right.$ and $\left.180^{\circ}\right)$ were varied with the same values from 0.1 until 1 , to analyse the impacts on the output current, $I_{\text {inverter }}$ and harmonic content, THD of the proposed Single-stage Microinverter. The irradiance and temperature of the PV module were fixed according to STC condition (Irradiance $1000 \mathrm{M} / \mathrm{w}^{2}, T_{\text {cell }} 25^{\circ} \mathrm{C}$ ). The switching frequency, $f_{s}$ was chosen at $50 \mathrm{kHz}$ since it produced lower harmonic content from previous analysis.

Figure 5 illustrates the trend of output current, $I_{\text {inverter }}$ and THD percentage represented by the red and blue line accordingly, with respect to modulation index, Ma. It is observed that as modulation index, Ma increased, the output voltage, $I_{\text {inverter }}$ also increased. When the modulation index, Ma increased, the time for the switches synthesized by SPWM to turn ON will also increase, resulting in much longer charging time. Therefore, the energy stored in the parallel-capacitor will increased. In the other hand, as modulation index, Ma increased, the harmonic percentage, THD will decreased from 5.28\% to $0.85 \%$, for modulation index, Ma 0.1 until 0.7 accordingly. However, harmonic content, THD will increased from $1.08 \%$ to $2.07 \%$, when the modulation index, Ma varied from 0.8 until 1 accordingly. The proposed Microinverter successfully followed the IEC 61727 standard for Single-stage Microinverter nominal power less than $10 \mathrm{~kW}$ and $50 \mathrm{~Hz}$ system that harmonic current's content, THD must be less than 4\%, represented by the dotted-black line in Figure 5. Thus, for controlling method in the future, the algorithm must be carefully pick out the modulation index that produces harmonic content below that dotted-black line of $4 \%$ THD standard.

\subsection{Trend of $\boldsymbol{P}_{R O C}$ of the $\mathrm{PV}$ with respect to irradiance and ambient temperature}

The irradiance and ambient temperature values were varied to analyse the impact on the expected power produced by the PV module, $P_{R O C}$. The expected power delivered by the PV-module can be calculated by using (1). Figure 6 illustrates the trend of expected power delivered by PV-module, $P_{R O C}$ when the irradiance and ambient temperature were varied from $100 \mathrm{M} / \mathrm{w}^{2}$ to $1000 \mathrm{M} / \mathrm{w}^{2}$ and $27^{\circ} \mathrm{C}$ until $45^{\circ} \mathrm{C}$ accordingly. Both black-dotted lines indicate the maximum power during STC, $P_{S T C}$ and NOCT, $P_{\text {NOCT }}$ with $330 \mathrm{~W}$ and $245 \mathrm{~W}$ respectively.

The blue and red lines represent the expected power, $P_{R O C}$ when ambient temperature and irradiance were fixed at $32^{\circ} \mathrm{C}$ and $600 \mathrm{M} / \mathrm{w}^{2}$ accordingly. It is clearly show that, expected power delivered by the PVmodule, $P_{R O C}$ producing slightly change of power when the irradiance is fixed. The expected power efficiency during STC and NOCT are around about $60.61 \%$ and $81.63 \%$ at the PV-module when the irradiance is fixed at $600 \mathrm{M} / \mathrm{w}^{2}$ while the ambient temperature is varied from $27^{\circ} \mathrm{C}$ until $45^{\circ} \mathrm{C}$. However, expected power delivered by the PV-module, $P_{R O C}$ is directly affected by the irradiance value received by the PV module. Thus, it can be concluded that, irradiance give more impact toward expected power, $P_{R O C}$ compared to the ambient temperature of the surrounding. If the Single-stage Microinverter is intended to produce power approximately or greater than power during NOCT condition, the $700 \mathrm{M} / \mathrm{w}^{2}$ irradiance must be achieved for higher expected power efficiency. The proposed Single-stage Microinverter with $700 M / w^{2}$ and above irradiance can be useful during around 10.05am until 15.05pm, Malaysian hour based on the sample daily solar irradiance profile given in [23]. 


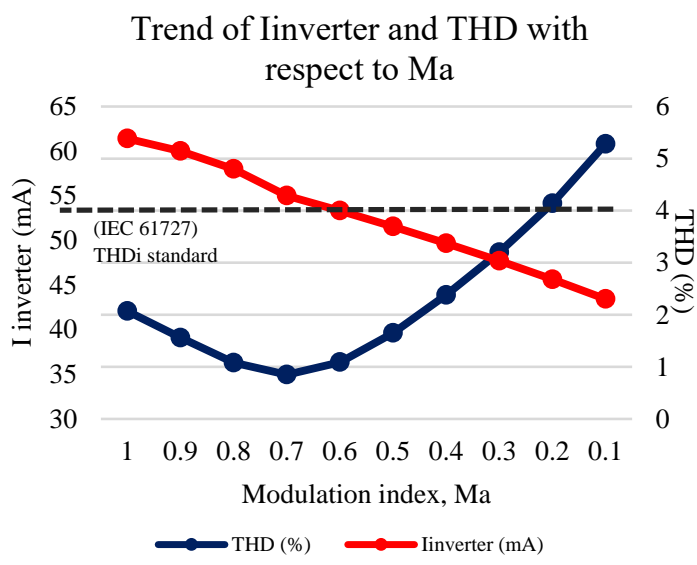

Figure 5. Trend of output current, $I_{\text {inverter }}$ and THD percentage with respect to modulation index, Ma.
Trend of $P_{R O C}$ of the PV with respect to Irradiance or Ambient temperature.

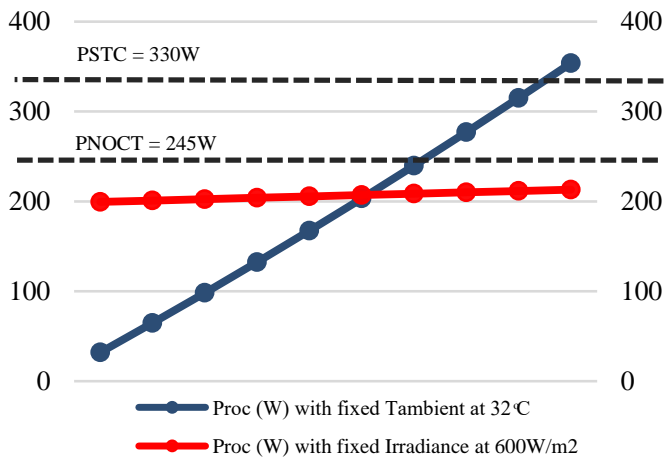

Figure 6. Expected power delivered by the $\mathrm{PV}$-module, $P_{R O C}$ with respect to Irradiance and Ambient temperature.

\section{COMPARISON BETWEEN PROPOSED MICROINVERTER TOPOLOGY AND OTHER TOPOLOGIES}

In this section, the proposed Single-stage Microinverter topology is compared with hybrid of classical inverter topologies explained in the Introduction section earlier, as shown in Table 4.

Based on the Table 4, it is clearly showing that the proposed Single-stage Microinverter topology only have 2-power switches, and only single-power switch is active during each cycle. The number of power switches have bigger impact on the cost, size and weight of the Microinverter unit. All of this papers $[1-9,26]$ supported this relationship of number of switches versus cost/size of the inverter.

F urthermore, based on the proposed Microinverter's operation modes discuss earlier, only 1-power switch is active during that single current path during positive or negative state; which leads to reduce the power losses. Since the power losses come from the dynamic voltage and current of the switch during the turn-off and turn-on transients, thus the smaller number of power switches are required to produce an output voltage reflected to lesser power losses $[11,17,18,26]$. The proposed Single-stage Microinverter topology were verified with different analysis to observe the trend of expected power, $P_{R O C}$ output current, $I_{\text {inverter }}$ and harmonic content, THD.

Table 4. Comparison of Single-stage Microinverter topologies

\begin{tabular}{ccccc}
\hline Ref & Microinverter Topology & $\begin{array}{c}\text { Power } \\
\text { Switches }\end{array}$ & Transformer & Additional Components \\
& Proposed Microinverter with Parallel-Capacitor & 2 & - & 2 Capacitors, 2 Diodes \\
\hline$[19]$ & Full-bridge with push-pull \& ripple-port converter & 10 & High-Frequency & - \\
{$[2]$} & Full-bridge with frequency conversion circuit & 6 & High-Frequency & 1 Inductor \\
{$[20]$} & Half-bridge with HF transformer & 4 & High-Frequency & 2 Capacitors \\
{$[7]$} & Flyback auxiliary circuit & 3 & Low-Frequency & 1 Capacitor, 3 Inductors, 3 Diodes \\
{$[24]$} & Coupled-inductor double-boost & 4 & - & 4 Inductors \\
{$[1]$} & Dual buck-boost & 5 & - & 1 Inductor, 2 Diodes \\
{$[26]$} & Boost PWM Inverter & 4 & - & 1 Capacitor \\
\hline
\end{tabular}

\section{CONCLUSIONS}

This paper presents a Single-stage Microinverter inverter with a new topology, which use a parallelcapacitor, transformer-less and integrating with only two (2)-power switches. A SPWM with two sinusoidal wave that $180^{\circ}$ apart are realized to initiate the switching sequences. The operation, switching state and output current for the proposed topology have been discussed. From the simulations results, the proposed Single-stage Microinverter topology were successfully tested to perceive the trend of expected power delivered by the PV-module with respect to irradiance and ambient temperature, the trend of output current and THD with respect to modulation index and switching frequency. The proposed Single-stage Microinverter topology has several advantages over other inverter topologies in terms of (i) total count of active devices, and (ii) the number of switches in current path which is directly related to power losses. 


\section{ACKNOWLEDGEMENTS}

This work was financially supported by the Ministry of Higher Education (MoHE), Malaysia. The authors would like to thank 1 Star Accrediation Under Asean Energy Management Scheme (AEMAS) Project No. 600-IRMI/DANA 5/3/BESTARI (KY) (001/2019) for financial supporting for the paper. The authors also would like to acknowledge the Center for Robotics and Industrial Automation (CeRIA), Fakulti Kejuruteraan Elektrik, Universiti Teknikal Malaysia Melaka, 76100, Durian Tunggal, Melaka, Malaysia and Centre of Electrical Power Engineering Studies (CEPES), Fakulti Kejuruteraan Elektrik, Universiti Teknologi MARA, 40450 Shah Alam, Selangor, Malaysia.

\section{REFERENCES}

[1] D. Petreuş, S. Daraban, I. Ciocan, T. Patarau, C. Morel, and M. Machmoum, "Low Cost Single Stage Microinverter with MPPT for Grid Connected Applications," Solar Energy, vol. 92, pp. 241-255, Jun. 2013.

[2] J. Jana, H. Saha, and K. Das Bhattacharya, "A Review of Inverter Topologies for Single-Phase Grid-Connected Phtovoltaic Systems," Renewable and Sustainable Energy Reviews, vol. 72, pp. 1256-1270, May 2017.

[3] Z. E. T. Ternifi, P. Petit, G. Bachir, and M. Aillerie, "New Topology of Photovoltaic Microinverter based on Boost Converter," Energy Procedia, vol. 119, pp. 938-944, 2017.

[4] H. A. Sher and K. E. Addoweesh, "Micro-inverters - Promising Solutions in Solar Photovoltaics," Energy for Sustainable Development, vol. 16, pp. 389-400, 2012.

[5] M. H. Zare, M. Mohamadian, and R. Beiranvand, "Single-Stage AC Module with Series Power Decoupling Capability for Connecting PV to a Single-Phase Power Grid," IET Power Electronics, vol. 10, no. 5, pp. 517-524, 2017.

[6] J. J. Shriginia and V. Sivachidhambaranathan, "PV Microinverter Topology based on Phase Shift Power Modulation Technique using Frequency Conversion Circuit," in 2016 Second International Conference on Science Technology Engineering and Management (ICONSTEM), vol. 119, pp. 281-284, 2016.

[7] M. Khalilian, M. Malekane Rad, E. Adib, and H. I. Farzanehfard, "New Single-Stage Soft-Switching Flyback Inverter for AC Module Application with Simple Circuit.," in The 6th Power Electronics, Drives Systems \& Technologies Conference (PEDSTC 2015 ), pp. 41-46, 2015.

[8] S. Z. Mohammad Noor, A. M. Omar, N. N. Mahzan, and I. R. Ibrahim, "A review of Single-Phase Single Stage Inverter Topologies for Photovoltaic System," in Proceedings - 2013 IEEE 4th Control and System Graduate Research Colloquium, ICSGRC 2013, pp. 69-74, 2013.

[9] S S. Z. Mohammad Noor, A. M. Omar, and M. A. M. Radzi, "Single-Phase Single Stage String Inverter for Grid Connected Photovoltaic System," Journal of Applied Mechanics and Materials, vol. 785, pp. 177-181, 2015.

[10] S. Kakar, S. M. Ayob, N. M. Nordin, M. S. Arif, A. Jusoh, and N. D. Muhamad, "A novel single-phase PWM asymmetrical multilevel inverter with number of semiconductor switches reduction," International Journal of Power Electronic and Drive System (IJPEDS), vol. 10, no. 3, pp. 1133-1140, 2019.

[11] R R. Hasan and S. Mekhilef, "Highly Efficient Flyback Microinverter for Grid-connected Rooftop PV System," Solar Energy, vol. 146, pp. 511-522, 2017.

[12] Techinavo.com, "Report - Global Solar Microinverter Market," 2016.

[13] N. Mohd Ali et al., "A review of different applications of Wireless Sensor Network (WSN) in monitoring rehabilitation," Journal of Telecommunication, Electronic and Computer Engineering, vol. 10, no. 1-9, 2018.

[14] R. Palanisamy, K. Vijayakumar, V. Venkatachalam, R. M. Narayanan, D. Saravanakumar, and K. Saravanan, "Simulation of various DC-DC converters for photovoltaic system," International Journal of Electrical and Computer Engineering (IJECE), vol. 9, no. 2, p. 917, 2019.

[15] A. Razi, M. N. Hidayat, and M. N. Seroji, "Microinverter Topology based Single-stage Grid-connected Photovoltaic System : A Review," Indonesian Journal of Electrical Engineering and Computer Science (IJEECS), vol. 11, no. 2, pp. 645-651, 2018.

[16] R. Hasan, S. Mekhilef, M. Seyedmahmoudian, and B. Horan, "Grid-Connected Isolated PV Microinverters: A Review," Renewable and Sustainable Energy Reviews, vol. 67, pp. 1065-1080, Jan. 2017.

[17] K. Y. Raval and V. J. Rupapara, "Novel Multilevel Inverter Design with Reduced Device Count," in 2018 International Conference on Current Trends towards Converging Technologies (ICCTCT), pp. 1-4, 2018.

[18] Z. Ahmad and S. N. Singh, "Improved modulation strategy for single phase grid connected transformerless PV inverter topologies with reactive power generation capability," Solar Energy, vol. 163, pp. 356-375, 2018.

[19] A. Aganza-Torres, V. Cárdenas, H. Miranda-Vidales, and J. Alcalá, "Decoupling Capacitor Minimization in HFlink Single-Phase Cycloconverter based Microinverter," Solar Energy, vol. 105, pp. 590-602, 2014.

[20] V. Berzan, I. Ermurachi, S. Postoronca, and C. Radu, "Micro-inverter for Photovoltaic Modules," in Proceedings of the 2016 International Conference and Exposition on Electrical and Power Engineering, EPE 2016, pp. 626631, 2016.

[21] R. K. Surapaneni and A. K. Rathore, "A Single-Stage CCM Zeta Microinverter for Solar Photovoltaic AC Module," 2015 IEEE Energy Conversion Congress and Exposition, ECCE 2015, vol. 3, no. 4, pp. 892-900, 2015.

[22] R. K. Surapaneni, "Solar Microinverter Topologies for Photovoltaic Generation Systems," 2017.

[23] SEDA Malaysia Grid-Connected Photovoltaic Systems Design Course, 2016.

[24] Y. Fang and X. Ma, "A Novel PV Microinverter with Coupled Inductors and Double-Boost Topology," IEEE Transactions on Power Electronic, vol. 25, no. 12, pp. 3139-3147, 2010. 
[25] H. Athari, M. Niroomand, and M. Ataei, "Review and Classification of Control Systems in Grid-tied Inverters," Renewable and Sustainable Energy Reviews, vol. 72, pp. 1167-1176, 2017.

[26] C C. Luciano, K. A. Aganah, M. Ndoye, and B. Oni, "New Switched-Multi-Source Inverter Topology with Optimum Number of Used Switches," in 2018 IEEE PES/IAS PowerAfrica, 2018, pp. 414-419.

[27] Trina Solar Datasheet, "Framed 72-cell Module," 2017.

[28] Webpage SEDA Malaysia www.seda.gov.my, access at September 15 ${ }^{\text {th }}, 2019$.

[29] Y. Cai, Y. Jia, and Y. Li, "Circuit Analysis of A Single Phase Micro- Photovoltaic Inverter," in 2012 Asia-Pacific Power and Energy Engineering Conference, pp. 1-4, 2012.

\section{BIOGRAPHIES OF AUTHORS}
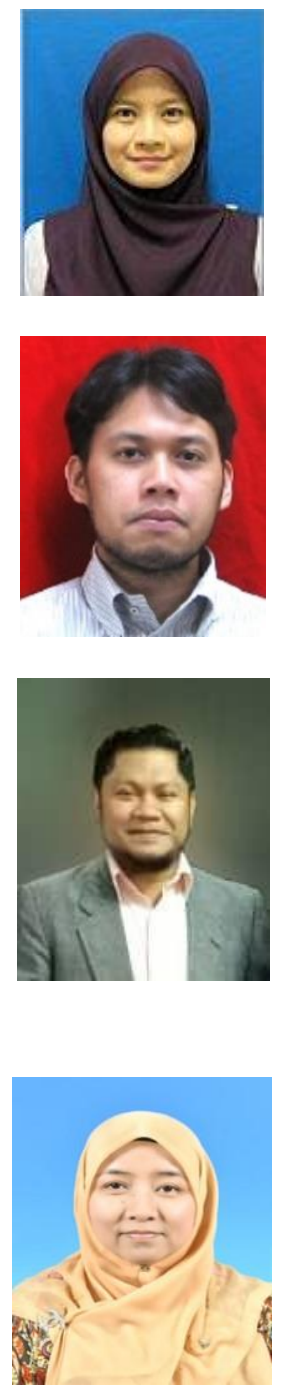

Atikah Razi received her Bachelor of Electrical Engineering in 2010 from Universiti Teknologi Malaysia and MSc Industrial Electronics \& Control from University of Malaya in 2013. She is with Center for Robotics and Industrial Automation (CeRIA), Fakulti Kejuruteraan Elektrik, Universiti Teknikal Malaysia Melaka, Jalan Hang Tuah Jaya, 76100 Durian Tunggal, Melaka (email: atikah@utem.edu.my). Currently lecturer on-leave pursuing PhD study in Centre of Electrical Power Engineering Studies, Universiti Teknologi MARA, Shah Alam, Selangor.

Dr. M. Nabil Hidayat received his Electrical and Electronic Engineering Bachelor's Degree, Masters of Engineering and Ph.D. Of Engineering in 2006, 2008 and 2011 respectively from the University of Tottori Japan. Currently he is a senior lecturer in University Teknologi MARA, Malaysia. He is a member of the Institute of Electronics, Information and Communication Engineers (IEICE) and member of the The Illuminating Engineering Institute of Japan. He is also a Registered Electrical Energy Manager (REEM) from Malaysian Electric Commission, Certified Energy Manager (CEM) and a Certified Professionals in Measurement and Verification (CPMV) from AEMAS.

Assoc. Prof. Dr. M. Nawawi Seroji is an Associate Professor at the Faculty of Electrical Engineering (FKE), UiTM. He received his first degree in Electrical Engineering from UiTM in 2001. He pursued his Master's degree in Power Electronics and Drives at The University of Birmingham and The University of Nottingham and successfully completed the doctoral degree in Electrical, Electronic \& Computer Engineering in 2008 from The University of Birmingham, UK. He has contributed to the Faculty and UiTM through various administrative posts: Dean of IPSis, Deputy Dean of IPSis, Head of Graduate Studies (IPSis) and Head of Centre for Postgraduate Studies (FKE). He is also a member to IEEE Professional association since 2003 and currently involved actively in research works pertaining to Power Electronic HighFrequency Converter.

Ts. Dr. S. Zaliha obtained Bachelor of Electrical Engineering (Hons) in 2005, MSc Power Electronics in 2008 and Ph.D. in Electrical Engineering in 2018 from Universiti Teknologi MARA (UiTM), Malaysia. She is currently a Senior Lecturer at the Faculty of Electrical Engineering, UiTM. She has authored and co-authored over 30 technical papers in indexed international journal and conferences. Her research interests are renewable energy, power electronics, modelingt and simulation, signal processing and embedded controller applications. 